\title{
EVALUATION OF ANXIOLYTIC POTENTIAL OF VARIOUS EXTRACTS OF TAMARINDUS INDICA FLOWERS
}

\author{
BALAKRISHNA VUYYALA ${ }^{1 *}$, SENTHIL KUMAR $\mathrm{D}^{2}$, THAKKALAPALLY LAKSHMI ${ }^{1}$
}

${ }^{1}$ Department of Pharmacology, Guru Nanak Institutions Technical Campus, Rangareddy, Telangana, India. ${ }^{2}$ Department of pharmacology, Annamalai University, Chidambaram, Tamil Nadu, India. Email: balakrishnavuyyala@gmail.com

Received: 01 August 2020, Revised and Accepted: 23 September 2020

\section{ABSTRACT}

Objective: The objective of this study was designed to gauge the antianxiety activity of varied extracts, namely, n-hexane, chloroform, ethyl acetate, and methanol of the flowers of Tamarindus indica using elevated plus maze (EPM) model in albino mice.

Methods: Coarsely powdered tamarind was powdered and subjected to exhaustive Soxhlet extraction using n-hexane, chloroform, ethyl acetate, and methanol. Solvents were recovered from all extracts using a rotary vacuum evaporator under reduced pressure. Albino mice have ministered orally with different doses of the extracts (i.e., 200 and $400 \mathrm{mg} / \mathrm{kg}$ ) and behavior was observed on the EPM. The standard (positive control) employed in the study Diazepam (2 mg/kg, P.O)

Results: Results indicate that the methanol extract of $T$. indica flowers showed maximum and significant dose-dependent effect at 200 and 400 mg/kg on EPM, the results were just like the standard antianxiety agent diazepam ( $2 \mathrm{mg} / \mathrm{kg}$ ). Locomotor activity evaluated with two different doses of $T$. indica (200 and $400 \mathrm{mg} / \mathrm{kg}$ ) using actophotometer. The results were shown to be decreased in a dose dependent model compared to control.

Conclusion: The methanol extract shows that the presence of polyphenols could be liable for the anxiolytic potential of T. indica. Hence, this plant could also be used as a useful antianxiety agent.

Keywords: Tamarind, Elevated plus maze, Diazepam, Anxiety.

(c) 2020 The Authors. Published by Innovare Academic Sciences Pvt Ltd. This is an open access article under the CC BY license (http://creativecommons. org/licenses/by/4. 0/) DOI: http://dx.doi.org/10.22159/ajpcr.2020.v13i11.39288

\section{INTRODUCTION}

Anxiety is a natural human state where in every body experience in their life. Anxiety is the foremost common psychological state problem within the world and it increases rapidly [1]. The mental disorders occurrence is increasing, and many severe adverse effects, addiction liabilities have been associated with long-term use of prescribed synthetic drugs. This paved the attention of researchers toward natural antianxiety sources.

It can prompt us to confront to handle difficult challenges that cause us to become psychologically disturbed and, unhealthy, produce anxious disorders such as panic attacks, phobias, and obsessional behaviors

Benzodiazepines, being a big category of agents used for hysteria [2], present a lean margin of safety between the anxiolytic effect and unwanted side effects, which has prompted researchers to gauge new compounds, especially plant-based drugs having less undesirable effects [3]

Tamarindus indica having family Fabaceae and subfamily Caesalpinaceae is a tropical evergreen tree in Asia [4-6]. In most of the tropical countries and in India, Sudan, Bangladesh, and Nigeria, T. indica is employed as an herbal drug contrary to pharmaceuticals $[7,8]$.

\section{MATERIALS AND METHODS}

\section{Authentication of plant material}

Fresh flowers of T. indica showed in Fig. 1 collected from the medicinal plants' farm, Theegalaguttapally, Karimnagar district, Telangana state. The identity of the plant was confirmed by Dr. E. Narasimha Murthy, Department of Botany, and Satavahana University. A representative sample of a plant specimen no. ENM/SU 0019022 has been deposited within the Herbarium-cum-museum of Satavahana University.

\section{Animals}

Swiss albino mice (either sex), bred at the Animal House, Guru Nanak Institute of Pharmacy, Hyderabad, were allowed a typical pellet diet and water ad-lib. These were of 6-8 weeks age weighing about $25 \pm 5 \mathrm{~g}$ of either sex were used. These were acclimatized to laboratory conditions for 7 days. Under the light/dark cycles, animals were retained at $22 \pm 3^{\circ} \mathrm{C}$ with $65 \pm 5 \%$ relative humidity. In each group contains six animals of both gender, through the entire anxiolytic screening was carried out randomly. The experimental protocol was approved by the Institutional Animal Ethics Committee of the institute (IAEC), School of Pharmacy, and Guru Nanak Institutions technical campus (the approval number: (06/GNIP/CPCSEA/IAEC/2019).

\section{Drugs and chemicals}

n-hexane $\left(60-80^{\circ} \mathrm{C}\right)$, chloroform (Ranbaxy Laboratory chemicals), and ethyl acetate and methanol (S. D. Fine Chemicals), all of LR grade, were employed for the extraction of the material. Diazepam (Jawa Pharmaceuticals Pvt. Ltd., Gurgaon) was employed as a typical standard drug for the evaluation of the antianxiety activity.

\section{Preparation of extracts}

Coarsely powdered tamarind (250 g) was powdered (\#60) and subjected to Soxhlet extraction by n-hexane, chloroform, ethyl acetate, and methanol [9]. Different extracts and the solvents were recollected using rotavapor under reduced pressure, and therefore, all the extracts were preserved in a vacuum desiccator containing anhydrous silica gel blue [10].

\section{Vehicle and standard}

carboxy methylcellulose $0.5 \% \mathrm{w} / \mathrm{v}$ aqueous containing $5 \%$ tween 80 was employed as a vehicle for making ready the suspension of different test doses of various extracts. Diazepam, hanged in the vehicle, was employed as the reference standard antianxiety drug. The vehicle alone obeys as control. 


\section{Preparation of doses}

The test material was dispersed in the vehicle in such concentrations as to receive 200 or $400 \mathrm{mg} / \mathrm{kg}$ extracts and $2 \mathrm{mg} / \mathrm{kg}$ of diazepam to mice in a volume various from 0.10 to $0.50 \mathrm{ml}$, peroral route, using a glass syringe fitted with an oral feeding tube.

\section{Acute oral toxicity studies}

The acute toxicity studies were carried for all the extracts according to the Organization for Economic Cooperation and Development guidelines 423 [11]

\section{Elevated plus-maze (EPM) model}

EPM comprising two open arms $(16 \mathrm{~cm} \times 5 \mathrm{~cm})$ and two closed arms $(16 \mathrm{~cm} \times 5 \mathrm{~cm} \times 12 \mathrm{~cm})$ having an open roof, keeps elevating $(25 \mathrm{~cm})$ from the floor for evaluating antianxiety behavior in animals [12]. During the whole experiment, mice are allowing to interact (socialize). Every precaution is taken to make sure that no external stimuli, aside from the peak of the maze, could invoke anxiety in mice. The dose treatment schedule is to maintain that each mice are having its turn on the EPM 60 min after the treatment of the saline, diazepam, or the plant material. Each mouse is placing in the middle of EPM with its head facing toward the open arm. During $5 \mathrm{~min}$ experiment, the behavior of the mice is recording as (a) no. (Number) of entries into the open arms and (b) mean time spent by the mouse in open arms [13].

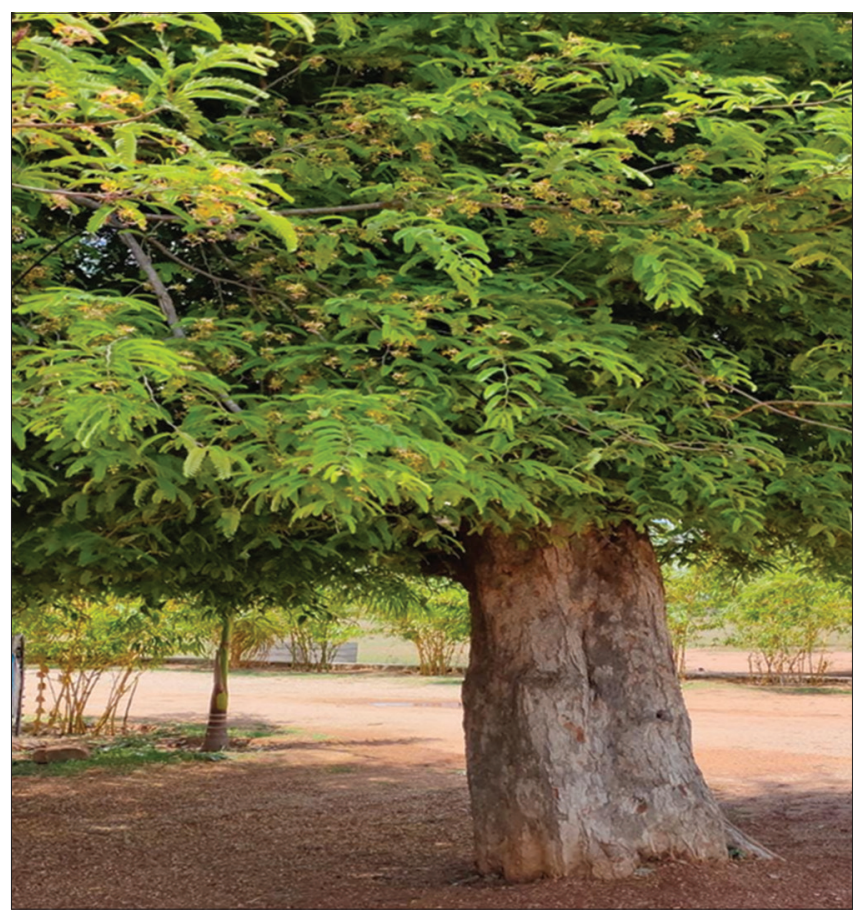

Fig. 1: Tamarindus indica plant

\section{Digital actophotometer}

Procedure

A continuous beam of sunshine from six lights are going to be made to fall on corresponding photoelectric cells, the photoelectric cells will get activated when an animal crosses the beam of light and thereby cuts off (crossing) the rays of light falling on it. These crossings are automatically counted for $10 \mathrm{~min}$ by the machine. The locomotor activity considered by the number of cuts off was taken as a parameter of the Mice [12]. Mice are placed in the digital actophotometer for $1 \mathrm{~h}$. After drug administration, the number of crossings is counted for ten minutes.

\section{Statistical analysis}

The data have been expressed as mean \pm standard error of the mean. Significant differences among the groups are assessing to use one-way analysis of variance (ANOVA). The test is followed by Tukey's multiple comparison test; $\mathrm{p}<0.05$ is considering as significant.

\section{Phytochemical screening}

Major constituents exhibiting maximum antianxiety in the extract were identified by phytochemical screening [14]

\section{RESULTS AND DISCUSSION}

- The yield of extracts (\%): The percentage yield $(\mathrm{w} / \mathrm{w})$ of various extracts, namely, n-hexane, chloroform, ethyl acetate, and methanol were $1.86,1.20,18.44$, and 8.38 , respectively. Table 1 shows the results of the phytochemical screening of various extracts of $T$. indica aerial parts

- Phytochemical screening: Methanol extract of T. indica flowers contains flavonoids, phytosterols, terpenoids, tannins, phenols, and carbohydrates.

\section{Pharmacological activity}

The antianxiety activity of Tamarindus indicia was evaluated by employing a widely used model, that is, EPM and locomotor activity. The mean number entries into open arms and time spent into open arms by mice after oral administration of doses $200 \mathrm{mg} / \mathrm{kg}$ and $400 \mathrm{mg} / \mathrm{kg}$ of all extracts.

Among various extracts methanolic extract of $T$. indica significantly increased the mean number of entries and mean time spent by mice in open arms of EPM apparatus at the various doses of $200 \mathrm{mg} / \mathrm{kg}$ and $400 \mathrm{mg} / \mathrm{kg}$ concerning control, thereby producing antianxiety activity. The various doses of 200 and $400 \mathrm{mg} / \mathrm{kg}$ exhibited significant anxiolytic effect dose-dependent manner shown in Table 2.

In the actophoptometer model, locomotor activity is measured and compared between the groups. Standard drug diazepam significantly decreased the number of crossings of light beams which are taken as a locomotor activity when compared to control $(344.80 \pm 12.68)$. Animals treated with $T$. indica $400 \mathrm{mg} / \mathrm{kg}$ exhibited a greater decrease in locomotor activity $(202.83 \pm 8.29)$ than animals treated with $T$. indica $200 \mathrm{mg} / \mathrm{kg}(234.17 \pm 19.35)$ and, therefore, showed a

Table 1: Phytochemical screening of various extracts of T. indicia flower extract

\begin{tabular}{lllll}
\hline Class of phytoconstituents & n-hexane extract & Chloroform extract & Ethyl acetate extract & Methanol extract \\
\hline Alkaloids & - & - & - & - \\
Anthraquinone glycosides & - & - & - & - \\
Cardiac glycosides & - & - & + & - \\
Steroids/triterpen oids & $-/-$ & $-/-$ & +- & $-/-$ \\
Saponins & - & - & - & + \\
Coumarins & - & - & + & + \\
Flavanoids & - & - & + & + \\
Tannins & - & - & - & + \\
Carbohydrates & - & - & & - \\
Proteins & - & - & & \\
\hline
\end{tabular}

+: Present, -: Absent 
Table 2: Anti-anxiety activity of various extracts of Tamarindus indica flower

\begin{tabular}{|c|c|c|c|c|c|}
\hline S.No. & Treatment & Dose (mg/kg) & $\begin{array}{l}\text { Mean* number of } \\
\text { entries in open arms }\end{array}$ & $\begin{array}{l}\text { Mean* time spent } \\
\text { in open arms (sec) }\end{array}$ & $\begin{array}{l}\text { Locomotor } \\
\text { activity }\end{array}$ \\
\hline 1. & Control & Vehicle & $2.3 \pm 0.21^{\mathrm{b}, \#}$ & $2.8 \pm 0.30^{\mathrm{b}, \#}$ & $344.80 \pm 12.68^{\mathrm{b}}$ \\
\hline 2. & Diazepam & 2.0 & $7.2 \pm 0.40^{\mathrm{a}, \#}$ & $14.5 \pm 0.42^{\mathrm{a}, \#}$ & $196.50 \pm 9.03^{\mathrm{a}, \#}$ \\
\hline \multirow[t]{2}{*}{3.} & n-hexane extract & 200 & $2.3 \pm 0.47^{\mathrm{b}, \#}$ & $3.8 \pm 0.30^{\mathrm{b}, \#}$ & $317.66 \pm 31.8^{\mathrm{b}, \#}$ \\
\hline & & 400 & $2.5 \pm 0.22^{\mathrm{b}, \#}$ & $4.3 \pm 0.21^{\mathrm{b}, \#}$ & $391.30 \pm 14.5^{\mathrm{b}, \#}$ \\
\hline \multirow[t]{2}{*}{4.} & Chloroform extract & 200 & $3.16 \pm 0.16^{\mathrm{b}, \#}$ & $3.3 \pm 0.42^{\mathrm{b}, \#}$ & $272.21 \pm 12.1^{\mathrm{b}, \#}$ \\
\hline & & 400 & $3.8 \pm 0.30^{\mathrm{b}, \#}$ & $4.8 \pm 0.30^{\mathrm{b}, \#}$ & $288.40 \pm 9.9^{\mathrm{b}, \#}$ \\
\hline 5. & & 400 & $3.3 \pm 0.33^{\mathrm{b}, \#}$ & $3.6 \pm 0.21^{\mathrm{b}, \#}$ & $258.33 \pm 16.7^{\mathrm{b}, \#}$ \\
\hline \multirow[t]{2}{*}{6.} & Methanol extract & 200 & $5.5 \pm 0.22^{\mathrm{a}, \#}$ & $8.8 \pm 0.30^{\mathrm{b}, \#}$ & $234.17 \pm 19.35^{\mathrm{b}, \#}$ \\
\hline & & 400 & $6.3 \pm 0.21^{\mathrm{a}, \#}$ & $13.5 \pm 0.22^{\mathrm{a}, \#}$ & $202.83 \pm 8.29^{\mathrm{a}, \mathrm{b}, \#}$ \\
\hline
\end{tabular}

${ }^{*} \mathrm{n}=6 .{ }^{\circledR} \mathrm{p}<0.05,{ }^{\$} \mathrm{p}<0.01,{ }^{\#} \mathrm{p}<0.001$. $^{\mathrm{a}}$ : vs. control; ${ }^{\mathrm{b}}$ : vs. diazepam. One way ANOVA followed by Tukey’s multiple comparison test.

statistically significant dose-dependent anxiolytic effect of $T$. indica (Table 2). The reduction in locomotor activity with $200 \mathrm{mg} / \mathrm{kg}$ and $400 \mathrm{mg} / \mathrm{kg}$ is significant in comparison to the standard group

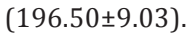

None of the other extracts exhibited antianxiety activity at any dose tested. Phytochemical screening of methanolic extract exhibited the occurrence of flavonoids, tannins, and carbohydrates. Flavonoids have shown antianxiety activity in various studies. The anxiolytic effect of flavonoids has been associated with its effect on the brain and spinal cord (central nervous system) [15] and benzodiazepine receptors [16,17]. Therefore, flavonoids of the methanolic extract of $T$. indica may be responsible for the antianxiety activity.

\section{CONCLUSION}

The present investigation reveals that the methanolic extract of T. indica manifested a maximum and significant dose-dependent effect at 200 and $400 \mathrm{mg} / \mathrm{kg}$ in mice with the help of EPM model and locomotor activity of anxiety. Further studies are under development to isolate bioactive constituent(s)/fraction from $T$. indica responsible for the antianxiety activity.

\section{ACKNOWLEDGMENTS}

The authors are thankful to the kind support and help of many individuals and organizations of Guru Nanak Institute of technical campus - School of Pharmacy, Hyderabad, for providing the best research facilities.

\section{AUTHORS' CONTRIBUTION}

Conception and design of the work were done by Dr. D Senthil Kumar and Dr. Thakkalapally Lakshmi. The entire experimental work and drafting were done by Mr. Balakrishna Vuyyala.

\section{CONFLICTS OF INTEREST}

The authors declare no conflicts of interest regarding the publication of this article.

\section{AUTHORS FUNDING}

Self.

\section{REFERENCES}

1. Eisenberg DM, Davis RB, Ettner SL, Appel S, Wilkey S, van Rompay M, et al. Trends in alternative medicine use in the United
States 1990-1997: Results of a follow-up national survey. JAMA 1998;280:1569-75.

2. Lader $\mathrm{M}$, Morton S. Benzodiazepine problems. $\mathrm{Br} \mathrm{J}$ Addict 1991;86:823-8.

3. Griffiths RR, Ator NA, Roache JD, Lamb RJ. abuse liability of triazolam: Experimental measurements in animals and humans. Psychopharmacol Ser 1987;3:83-7.

4. Kobayashi A, Adenan ML, Kajiyama SI, Kanzaki H, Kawazu K. A cytotoxic principle of Tamarindus indica, di-n-butyl malate and the structure-activity relationships of its analogs. J Biosci 1996;51:233-42.

5. Ferrara L. Antioxidant activity of Tamarindus indica L. Ingredienti Aliment 2005;4:13-5.

6. Kristensen M, Balslev H. Woody plants availability,perceptions and use among the Gourounsi in Burkina Faso. Biodivers Conserv 2003;12:1715-39.

7. Dagar JC, Singh G, Singh NT. Agroforestry crops evolution was carried with tamarind (Tamarindus indica), teak (Tectoma grandish) and maharukh (Ailanthus excelsa), and on reclaimed salt-affected soils. $\mathrm{J}$ Trop For Sci 1995;7:623-34.

8. Balakrishna V, Kumar DS, Lakshmi T. Tamarindus indica L. (Fabaceae): Extent of explored use in traditional medicine. Asian J Pharm Clin Res 2020;13:28-32.

9. Julia MF. Tamarind (Tamarindus indica L.) its Food, Medicinal and Industrial Uses. United States: University of Miami; 1958. p. 288.

10. Trease EG, Evans WC. Textbook of Pharmacognosy. $12^{\text {th }}$ ed. Singapore: Alden Press; 1983.

11. OECD Guidelines for the Testing of Chemicals No. 423, Acute Oral Toxicity-Acute Toxic Class Method; 2001.

12. Paladini AC, Marder M, Viola H, Wolfman C, Wasowaki C, Medina JH. Flavonoids and the central nervous system: From forgotten factors to potent anxiolytic compounds. J Pharm Pharmacol 1999;51:519-26.

13. Halemani D. Evaluation of anti-anxiety activity of methanol extract of Aegle maemelos (Bael fruit tree) leaves in rats. IOSR J Dent Med Sci 2015;14:1-5.

14. Ashwani K, Jitender S, Anupam S. Comparative study of antianxiety activity of Argyreia speciosa Linn. (Roots), Caesalpinia digyna rottler (Roots), and Sphaeranthus indicus Linn. (Flowers). Int J Pharm Sci Res 2015;6:4226-9.

15. Medina JH, Viola H, Wolfman C, Marder M, Wasowski C, Clavo D, et al. Neuroactive flavonoids: New ligands for the benzodiazepine receptors. Phytomedicine 1997;5:235-43.

16. Kulkarni SK, Reddy DS.Testing of antianxiety agents by animal behaviour models. Methods Find Exp Clin Pharmacol 1996; 18:219-40

17. Wolfman C, Viola H, Paladini A, Dajas F, Medina JH. Possible anxiolytic effects of chrysin, a central benzodiazepine receptor ligand isolated from Passiflora coerulea. Pharmacol Biochem Behav 1994;47:1-4 